\title{
Pengembangan Keterampilan Berkomunikasi Anak Usia Dini melalui Metode Bermain Peran
}

\author{
Dinar Nur Inten \\ Fakultas Tarbiyah dan Keguruan, Universitas Islam Bandung, Jl. Ranggading No. 8 Bandung 40116 \\ E-mail: dinar_nurinten@yahoo.com
}

\begin{abstract}
Abstrak: Di era globalisasi dan teknologi saat ini semua orang tidak bisa terlepas dari kegiatan yang menggunakan teknologi. Begitu pula dengan anak usia dini. Seringnya anak menggunakan teknologi gadget, smartphone dan minimnya pengawasan serta pendampingan dari orangtua menjadikan kemampuan komunikasi anak tidak berkembang secara optimal. Padahal, keterampilan berkomunikasi memiliki peranan penting dalam kehidupan anak. Penelitian ini menggunakan metode penelitian tindakan kelas, yaitu suatu bentuk penelitian yang bersifat reflektif dengan melakukan tindakan tertentu untuk meningkatkan pengembangan kemampuan komunikasi anak usia dini. Tindakan yang dilakukan adalah penggunaan metode bermain peran yang terdiri atas tiga tema, yaitu: rumah, pasar, dan rumah sakit dalam pembelajaran yang berlangsung selama tiga siklus. Hasil penelitian menunjukkan bahwa setelah pembelajaran disampaikan melalui metode bermain peran, baik pada tema rumah, pasar ataupun rumah sakit terlihat adanya peningkatan kemampuan komunikasi anak. Hal ini dapat dilihat pada grafik peningkatan yang terjadi dari prasiklus dan siklus tiga, di mana pada prasiklus rata-rata anak masih berada pada poin satu sedangkan pada siklus tiga rata-rata anak berada pada poin tiga, yaitu sudah mampu berkomunikasi. Anak dapat menyampaikan berbagai hal yang ada dalam pikiran dan imajinasinya melalui keterampilan berkomunikasi yang ia miliki.
\end{abstract}

Kata kunci: keterampilan berkomunikasi, anak usia dini, metode bermain peran

\begin{abstract}
: in this era of globalization and technology everyone can not be separated from activities that use technology included early childhood. the high frequency of gadget and smart phones usage in children and the lack of supervision and assistance from parents makes the communication skills of children are not develop optimally. In fact, communication skills have an important role in the child's life. This research used classroom action research method that is a form of research that is reflective by doing certain actions to improve the development of communiction ability of early childhood. The action taken was the use of role playing methods consisting of three themes : home, market and hospital in learning process that took place in three cycles. The results showed that after the learning delivered through role play methods, either on the theme of the house, market, or hospital, there was an increase in the communication ability of the children. This can be seen in the increase graph that occurred from pre cycle and the third cycle, where in the average pre cycle the child is still at point one while in the third cycle the average children is at point three that is already able to communicate. The children can conveyed things in their mind and imagination through their communication skills.
\end{abstract}

Keywords: communication skills, early childhood, role play 


\section{PENDAHULUAN}

Masa kanak-kanak atau masa usia dini adalah masa yang sangat fundamental bagi kehidupan anak kelak. Berbagai hal yang diberikan dan diterima anak waktu kecil akan menjadi dasar serta pijakan bagi masa depannya.

Keterampilan berkomunikasi merupakan salah satu hal yang memiliki peranan penting bagi kehidupan anak. Melalui komunikasi yang baik anak dapat menyampaikan segala pemikirannya kepada orang lain, baik secara lisan ataupun tulisan. Keterampilan komunikasi yang baik, yaitu di mana bahasa lisan dan tulisan anak dapat dengan mudah dipahami oleh orang lain.

Keterampilan berkomunikasi bukan hanya dapat mengantarkan anak mampu dalam aspek akademik saja, tetapi keterampilan berkomunikasi akan berpengaruh terhadap berbagai aspek perkembangan anak salah satunya akan membawa anak diterima oleh lingkungan sosial di mana ia berada.

Keterampilan komunikasi yang baik dapat anak-anak peroleh dari aktivitas yang sangat dekat dengan dunianya, yaitu melalui bermain. Namun sangat disayangkan, saat ini lahan untuk bermain anak sangatlah jarang, bahkan susah untuk didapatkan. Rata-rata ruang bermain anak Indonesia adalah 2.000 $\mathrm{m} 2$ /anak, lebih rendah dari kebanyakan anak di negara-negara berkembang di kawasan Asia lainnya dan sangat kecil jika dibandingkan dengan anak-anak dari negara Barat (sekitar $10.000 \mathrm{~m} 2 /$ anak) (Pramesti, 2004).

Kurangnya lahan hijau untuk bermain menjadikan anak cenderung memilih bermain di dalam rumah dengan menonton televisi ataupun asik bermain gadget. Televisi, komputer dan gadget telah menggantikan permainan kasti, gobak sodor, kucing-kucingan, yang sebenarnya dibutuhkan anak untuk mengoptimalkan aspek perkembangan yang ada dalam dirinya. Hal ini dapat berdampak buruk terhadap perkembangan anak, yaitu anak kurang mampu mengenali berbagai emosi yang terjadi. Akibatnya, anak tidak dapat merespons hal-hal yang terjadi di sekitarnya dan anak-anak menjadi cenderung lebih ogois dan individualis.

Pola asuh orangtua yang lebih membiarkan anak asyik dengan berbagai media di rumah. Salah satunya medium televisi. Melalui televisi anak banyak menonton sinetron yang kerap menampilkan adegan yang bermasalah dan negatif. Tak heran kalau anak-anak kecil sekarang sudah berani marah kepada orangtua seperti yang mereka lihat di televisi. Hal ini menyebabkan komunikasi yang dilakukan anak, berperilaku kasar dan tidak sehat.

Begitu juga dengan gadget. Menurut dr. Tjhin Wiguna, SpKJ (K), anak usia dini tidak disarankan menggunakan gadget karena hal ini dapat mengakibatkan anak tidak dapat belajar secara alami bagimana berkomunikasi dan bersosialisasi. Terbatasnya respons anak akan mengganggu perkembangan kemampuannya untuk beradaptasi dan bergaul (Kompas, 2013).

Dunia anak yang sebenarnya adalah dunia bermain. Bermain memiliki manfaat yang sangat penting untuk pertumbuhan dan perkembangan, baik fisik maupun psikis anak. Melalui permainan, anak-anak menguji dugaan mereka tentang bagaimana dunia berfungsi, yang seringkali menghasilkan kesimpulan yang cemerlang walaupun kadang salah (Nurani, 2009: 144). Dalam bermain, anak bereksplorasi dan bereksperimen terhadap berbagai hal yang ada di sekitarnya. Anak belajar saat mereka bermain.

Bermain dan keterampilan komunikasi adalah dua hal yang penting dirasakandandilakukanolehanak. Melalui permainan, anak dapat menyampaikan 
sekaligus mengomunikasikan berbagai ide yang dimilikinya dengan mudah tanpa beban serta dengan ekspresi yang bebas pula. Sholehudin (1997: 54) mengatakan, melalui bermain anak dapat mempraktikkan kemampuan dan keterampilan yang dikuasainya serta mencoba, meneliti dan menemukan hal-hal baru, seperti ketika orangtua mengajak anak-anak untuk melakukan percakapan santai sambil memasak, berkebun, ataupun ketika makan malam. Percakapan tersebut akan membangun komunikasi antara orangtua dan anak yang lebih menyenangkan dan nyaman serta bermakna. Percakapan di waktu makan, apakah itu dalam bentuk eksplanatori atau dalam bentuk narasi, berhubungan positif dengan naiknya jumlah kosakata yang dimiliki anak (Otto, 2015:201).

Bermain peran atau bermain tentang kehidupan bukanlah kegiatan mudah, remeh dan sepele seperti anggapan orang dewasa. Menurut Beaty (2014: 421) anak-anak yang sering berlatih dengan permainan drama seringkali mereka yang paling berhasil dalam hidup saat dewasa. Anak-anak yang tidak diperbolehkan atau atau tidak didorong terlibat dalam permainan itu mungkin merugi saat dewasa, karena mereka kehilangan dasar penting dalam kemampuan sosial, intelektual, dan perilaku kreatif.

Oleh karena itu, di Taman KanakKanak pembelajaran melalui metode bermain peran sangat diperlukan untuk membantu pengembangan komunikasi anak-anak prasekolah. Hasil penelitian mengenai penggunaan metode bermain peran untuk mengembangkan komunikasi anak, menemukan adanya kemajuan dalam kompleksitas strategi komunikasi yang digunakan anak usia 2,3,4, dan 5 tahun, yaitu pada penggunaan variasi intonasi dan menggunakan ikatan semantik untuk mengembangkan ucapan temannya (Musthafa, 2008: 9-10). Hal ini menunjukkan bahwa metode bermain peran dapat membantu pengembangan komunikasi anak usia dini.

Penelitian ini menjadikan metode bermain peran sebagai salah satu alternatif pengembangan keterampilan berkomunikasi untuk anak. Melalui metode bermain peran, anak dapat mengembangkan rasa percaya diri, sehingga memiliki keberanian untuk menyampaikan pendapatnya kepada orang lain. Anak pun dapat menghargai pendapat orang lain.

Suasana yang nyaman dan banyaknya kesempatan yang diberikan pada kegiatan bermain peran membantu anak untuk dapat mengekspresikan dan mengomunikasikan berbagai hal yang ada pada dirinya kepada orang lain. Berdasarkan penelitian yang telah dilakukan menunjukkan bahwa anakanak usia 20 bulan dengan ibu yang aktif mengajaknya berkomunikasi, memiliki kemampuan penguasaan kosakata rata-rata sebanyak 131 bahkan lebih (Doughherty, 2003: 19).

Melalui metode bermain, peran anak akan dibawa ke dunia permainan yang penuh petualangan seakan-akan mereka sedang menjadi aktor dari sebuah film yang disukainya. Di sana, anak dapat melakukan dan mengekspresikan berbagai hal yang ia kehendaki dalam perannya tanpa takut salah atau ada yang memarahinya. Mereka akan larut dalam tokoh yang diperankannya. Kemampuan anak untuk menyesuaikan ujaran sesuai dengan konteks sosial dan linguistik merupakan perkembangan yang penting supaya anak mampu berkomunikasi secara efektif di beragam konteks.

\section{Komunikasi dan metode bermain peran}

Pengertian komunikasi adalah pemindahan suatu arti melalui suara, tanda, bahasa tubuh, dan simbol (Dhinie, 2008: 1.15). Bahasa adalah simbol sistem yang teratur untuk mentrasfer arti tersebut. Bahasa adalah suatu modifikasi komunikasi 
yang meliputi sistem simbol khusus yang dipahami dan digunakan sekelompok individu untuk mengomunikasikan berbagai ide dan informasi. Seperti bahasa Indonesia menggunakan 26 huruf (a-z) untuk menulis banyak kata. Sistem simbol dalam bahasa meliputi: fonologi, morfologi, sintaksis, semantik, dan pragmatik.

Ketika berkumpul orang-orang dalam suatu tempat, maka di sana akan terjadi komunikasi, baik verbal maupun nonverbal. Begitu pula dengan anak-anak, biasanya mereka akan membicarakan berbagai hal dengan teman-teman atau orang-orang yang berada di sekitarnya tapi ada pula sebagian anak yang hanya menggunakan isyarat atau bahasa tubuh dalam berkomunikasi. Maka komunikasi bisa dikatakan juga proses mengirimkan, menerima, dan memahami gagasan dan perasaan dalam bentuk verbal dan nonverbal secara disengaja ataupun tidak disengaja (Iriantara, 2014: 3).

Menurut Mulyana (2005), ada beberapa faktor yang memengaruhi komunikasi,yaitufisik(cuaca, suhu, udara, dan warna dinding), psikologis (sikap, kecenderungan, dan prasangka), sosial (norma kelompok dan nilai sosial) dan waktu (yaitu saat komunikasi dilakukan (Iriantara, 2014: 5). Oleh karena itu, untuk mengembangakan komunikasi pada anak usia dini haruslah memerhatikan hal-hal di atas, termasuk metode yang digunakan untuk mengembangkan komunikasi dalam pembelajaran anak usia dini.

Pada sebagian anak, menyampaikan ide atau gagasan kepada orang lain, atau sekadar berbicara dengan orang di sekitarnya, merupakan hal yang sulit dan menakutkan. Melalui metode yang dapat menciptakan suasana yang nyaman, aman, dan menyenangkan dapat membantu mengembangkan komunikasi pada anak usia dini.

\section{Metode bermain peran}

Pengertian metode bermain peran adalah memerankan tokoh-tokoh atau benda-benda di sekitar anak dengan tujuan untuk mengembangkan daya khayal (imajinasi), dan penghayatan terhadap bahan pengembangan yang dilaksanakan (Dhinie, 2008: 7.32). Dengan demikian yang dimaksud dengan metode bermain peran pada pembelajaran anak usia dini adalah sebuah cara agar anak-anak dapat mengembangkan kreativitas dan imajinasinya untuk memerankan tokohtokoh yang ada di sekitarnya. Tokohtokoh yang diperankan anak, baik berupa orang, binatang, maupun benda-benda yang dikenal oleh anak.

Tujuan dilaksanakannya metode bermain peran pada tingkat anak usia dini adalah untuk membantu mengembangkan kreativitas, daya khayal, dan keberanian anak untuk menyampaikan gagasan, ide-ide yang ada dalam pikirannya serta membantu anak untuk mampu memecahkan masalah yang dialaminya. Nurbiana Dhinie (2008: 7.33), menyebutkan lima tujuan metode bermain peran; di antaranya: pertama, mengeksplorasi perasaan-perasaan dan memperoleh wawasan tentang sikap dan nilai-nilai. Kedua, mengembangkan keterampilan dan sikap dalam memecahkan masalah. Ketiga, melatih anak berbicara lancar dan melatih membuat kesimpulan. Keempat, membantu perkembangan intelegensi dan yang kelima menciptakan suasana pembelajaran yang menyenangkan.

Jenis kegiatan bermain peran pada anak usia dini seperti bermain peran dokter, guru, tukang sayur, ibu, anak, penjual dan pembeli, serta masih banyak yang lainnya yang berkenaan dengan kehidupan di sekitar anak. Melalui kegiatan bermain peran, selain anak belajar berbicara dan mengomunikasikan pemikirannya, anak pun belajar menyimak apa yang disampaikan teman-temannya serta melihat dan memerhatikan berbagai peran yang dimainkan. 
Langkah-langkah dalam pelaksaan metode bermain peran adalah sebagai berikut. Pertama, menyiapkan naskah, alat, media, dan kostum yang akan digunakan. Kedua, menerangkan teknik bermain peran dengan cara sederhana yang mudah dimengerti dan dipahami anak. Ketiga, memberikan kebebasan pada anak untuk memilih peran yang disukainya. Keempat, menentukan sebagian anak yang akan menjadi penonton dan pendengar. Kelima, menyarankan kalimat pertama yang sebaiknya di ucapkan oleh anak. keenam, menghentikan permainan ketika sedang mencapai puncaknya, dan melakukan diskusi dengan para penonton dan pendengar mengenai masalah yang sedang terjadi dan bagaimana pemecahannya. Dan langkah yang terakhir setelah kegiatan selesai, guru melakukan evaluasi terhadap peran yang dimainkan anak (Dhinie, 2008: 7.35).

Dalam metode bermain peran, guru berperan sebagai fasilitator, pengarah, dan pengamat permainan. Guru yang mengarahkan dan bertanggung jawab pada kegiatan awal bermain peran anak. Guru pula yang memberikan motivasi, mengajukan pertanyaan, dan memberikan komentar agar anak dapat bebas mengekspresikan gagasan dan pemikirannya, sehingga anak-anak mengetahui bagian mana yang masih membutuhkan eksplorasi lebih dalam. Setelah permainan berlangsung, maka guru dapat menentukan kapan permainan berakhir dan memimpin diskusi bersama anak-anak berhubungan dengan perannya.

Menurut Lilis Madyawati dalam bukunya, Strategi Pengembangan Bahasa pada Anak, manfaat dari bermain peran adalah: membangun kepercayaan diri pada anak, mengembangkan kemampuan berbahasa, meningkatkan kreativitas dan akal, membuka kesempatan untuk memecahkan masalah, membangun kemampuan sosial dan empati, memberi anak pandangan positif (2015: 158-
159). Bermain peran akan membantu pengembangan aspek emosional, sosial, mental, intelektual, moral agama dan fisik anak, karena dalam bermain peran, selain anak di tuntut untuk mampu bertutur secara verbal, anak-anak pun di tuntut untuk mampu mengkomunikasikan gagasannya melalui bahasa tubuhnya.

Dalam kegiatan bermain peran anak menjadi aktor, sutradara, penonton aktor lain, dan pengumpan bagi anak lain, Bahkan terkadang, anak juga menjadi komentator pemain lain melalui kegiatan berbisik-bisik ketika permainan sedang berlangsung. Menurut Beaty (2015:421), kebebasan dan waktu yang di berikan pada anak-anak membuat mereka bebas berpartisipasi dalam mengembangkan kreatifitas dan imajinasinya.

Melalui bermain peran, selain anak belajar memainkan berbagai peran anak pun akan memperoleh banyak kosakata baru yang dapat digunakan untuk membangun komunikasi yang lebih baik dengan teman-temannya. Menurut Nurgiantoro (2015: 43), anak akan belajar cepat karena bahasa yang diperolehnya berada dalam konteks pemakaian yang sesungguhnya.

\section{METODE}

Metode penelitian yang digunakan adalah penelitian tindakan kelas (PTK). Penelitian tindakan menggabungkan kegiatan penelitian atau pengumpulan data dengan penggunaan hasil penelitian atau pengumpulan data. Kegiatan ini dilakukan secara timbal balik membentuk spiral, rencana, tindakan, pengamatan, dan refleksi.

Prosedur penelitian tindakan kelas Kemmis \& Mc Taggart adalah dipandang sebagai siklus spiral yang terdiri atas komponen perencanaan, tindakan, pengamatan, dan refleksi, yang selanjutnya akan diikuti dengan siklus spiral, untuk lebih jelasnya lihat gambar 1 .

Penelitian tindakan kelas ini 


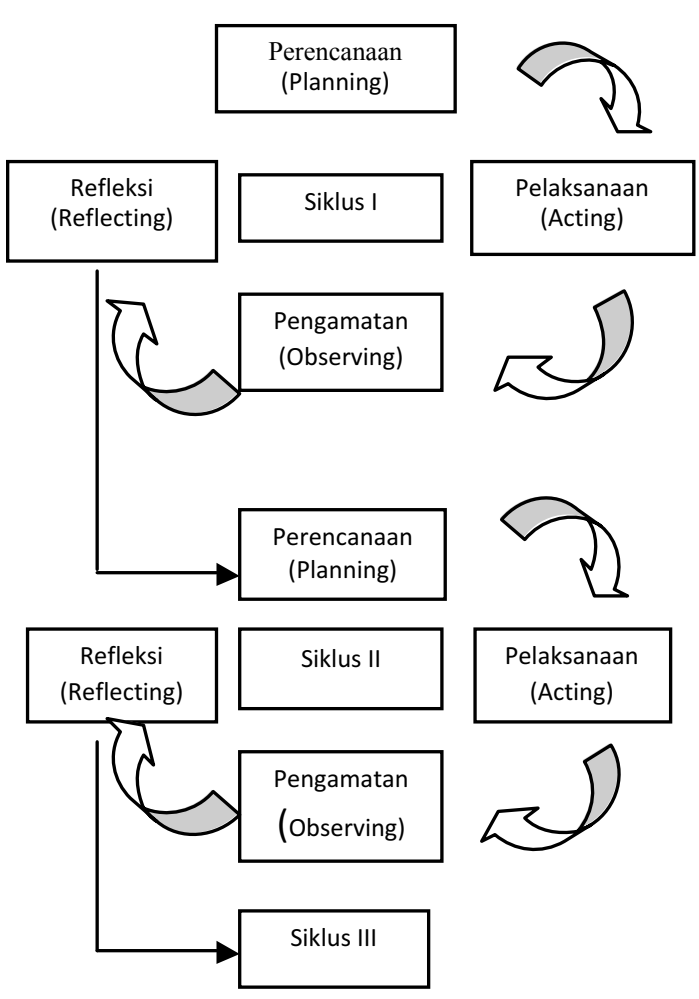

GAMBAR 1. Siklus Spiral Prosedur Penelitian Tindakan Kelas

(Afrilianto \& Hendriana, 2017: 43)

dilaksanakan pada kelompok A RA AlMuqoddasah Desa Jagabaya, Kecamatan Cimaung, dengan jumlah anak 10 orang. Dalam penelitian ini dilakukan 3 siklus, yaitu sebagai berikut:

\section{Tahapan penelitian siklus 1}

Sebelum tindakan dilakukan diadakan pretest terlebih dahulu untuk mengetahui gambaran awal kegiatan pembelajaran yang biasa dilaksanakan. Kemudian setelah pretest baru dilaksanakan tindakan, yaitu kegiatan pembelajaran melalui metode bermain peran.

Perencanaan. Pada tahap ini peneliti menyiapkan RKM (Rencana Kegiatan Mingguan), RKH (Rencana Kegiatan Harian), Skenario kegiatan yang akan dilaksanakan berkaitan dengan pembelajaran melalui metode bermain peran, lembar penilaian perkembangan anak dan lembar observasi.
Tindakan. Pelaksanaan tindakan siklus pertama dilakukan dalam tiga pertemuan atau selama satu minggu. Pada pertemuan pertama, guru menyampaikan pembelajaran dengan tema rumah; pada pertemuan kedua guru menyampaikan pembelajaran dengan tema pasar; dan pada pertemuan ketiga guru menyampaikan pembelajaran dengan tema rumah sakit.

Pada setiap pertemuan, pembelajaran disampaikan melalui metode bermain peran, yaitu anakanak dibagi peran sesuai tema yang akan dikenalkan. Guru pun menyiapkan berbagai media yang berhubungan dengan tema dan tokoh yang akan diperankan oleh anak.

Observasi. Observasi dilakukan selama proses pembelajaran dengan menggunakan lembar observasi yang telah disediakan dan selama kegiatan pembelajaran pun guru mencatat perkembangan keterampilan komunikasi anak dalam lembar tes atau lembar unjuk kerja yang telah disesuaikan dengan capaian pembelajaran yang diharapkan melalui metode bermain peran.

Refleksi. Pada tahap ini, peneliti bersama guru melakukan evaluasi dari pelaksanaan tindakan pada siklus I yang digunakan sebagai bahan pertimbangan perencanaan pembelajaran siklus berikutnya. Pada siklus I keterampilan komunikasi anak yang diharapkan belum tercapai maka dilakukan perbaikan yang dilaksanakan pada siklus kedua.

\section{Tahapan penelitian siklus II}

Siklus II dilakukan dengan maksud sebagai hasil refleksi dan perbaikan terhadap pelaksanaan pembelajaran pada siklus I. Sedangkan kegaiatan pada siklus III dimaksudkan sebagai hasil refleksi dan perbaikan terhadap pelaksanaan pembelajaran pada siklus II. Tahapan tindakan siklus II dan siklus III mengikuti tahapan siklus I.

Adapun instrumen yang 
digunakan dalam penelitian ini, yaitu: lembar observasi, lembar tes atau unjuk kerja serta dokumentasi. Data yang telah dikumpulkan melalui instrumen penelitian dikategorikan dan diklasifikasikan kemudian dideskripsikan dalam bentuk narasi dan grafik. Semua data yang terkumpul dikategorisasikan sehingga bisa memberikan penjelasan terhadap penemuan dari penelitian yang telah dilakukan.

\section{TEMUAN DAN PEMBAHASAN}

Keterampilan komunikasi anak usia dini tampak pada cara mereka bergaul dan bersosialisasi dengan teman sebayanya. Anak-anak yang memiliki rasa percaya diri yang tinggi mereka akan bergaul dengan cukup baik. Menurut Morrison (2012: 221), perkembangan sosial dan emosi yang merupakan salah satu aspek perkembangan pendukung keterampilan komunikasi anak, yang positif memudahkan anak belajar dengan lebih baik dan berhasil dalam semua aktivitas dan dalam hidup.

Pada pendidikan anak usia dini, anak didorong untuk menyampaikan pengalamannya melalui berbagai bentuk komunikasi seperti: lisan, tulisan, seni dan permainan. Melalui hal ini anakanak dapat mengontruksi pengalamannya secara praktis tanpa merasa terbebani, sekaligus dapat mengembangkan aspek kognitif dan bahasa anak. Berdasarkan penelitian Loban, menyimpulkan bahwa anak-anak yang diidentifikasi memiliki kemampuan bahasa yang tinggi pada usia dini, maka ke depannya selama 13 tahun secara konsisten memperlihatkan kemampuan bahasa yang tinggi pula meliputi: kemampuan mengekspresikan ide-ide mereka serta berpartisipasi aktif dalam percakapan, kemampuan membaca dan menulis yang baik, kosakata yang lebih banyak, kalimat dan paragraf yang lebih kompleks, serta kemampuan mendengarkan yang lebih efektif (Otto :
2015: 26).

Guru anak usia dini dituntut untuk mampu memberikan rangsangan agar anak-anak mampu berkomunikasi, baik dengan mengajukan berbagai pertanyaan ataupun mengemas kegiatan melalui permainan. Menurut Beaty (2015: 133), permainan merupakan alat utama bagi pengembangan sosial anakanak. Permainan mendorong interaksi sosial. Anak-anak belajar cara berunding, menyelesaikan konflik, menyelesaikan masalah, saling bergaul, mengambil giliran, bersabar, bekerjasama, dan berbagi. Permainan membantu anak untuk memahami bagaimana berkomunikasi dengan baik.

Kegiatan yang dikemas melalui permainan dapat menciptakan suasana yang nyaman, rileks, dan menyenangkan serta banyaknya kesempatan bagi anak untuk: berkreasi, menyampaikan pendapatnya, bebas mencoba berbagai alat peraga, bercerita, bertanya, sehingga anak dapat mengeksplor berbagai hal yang pada diri dan sekitarnya.

Pada penelitian ini, tema yang digunakan adalah tema-tema yang dekat dan berada di sekitar anak, yaitu tema: rumah, pasar, dan rumah sakit. Melalui tema-tema yang ada di sekitar anak, akan mendorong mereka untuk menghidupkan kembali pengalaman yang pernah dilaluinya, cerita-cerita yang pernah di dengarnya dan atau menciptakan cerita mereka sendiri dalam wujud kenyataan (Otto, 2015: 323).

Pada setiap tema dalam penelitian ini, anak dilibatkan untuk memerankan tokoh tertentu. Misalnya, pada tema rumah anak-anak memerankan tokoh ibu, bapak, kakak, adik. Sedangkan pada tema pasar, anak-anak memerankan tokoh penjual dan pembeli. Pada tema pasar ini pun anak-anak dikenalkan pula pada nominal uang dan berbagai jenis barang yang dijual di pasar, serta bagaimana proses jual-beli dilakukan. Tema rumah 
sakit, anak-anak memerankan tokoh dokter, pasien, dan suster atau perawat.

Kegiatan bermain peran dilakukan oleh anak dan dibantu dengan berbagai media pendukung tokoh yang diperankan. Kegiatan bermain peran yang mendapatkan waktu yang banyak, ruang yang luas serta beragam properti yang dibutuhkan akan membuat perkembangan bahasa anak semakin tingi (Otto, 2015: 324). Seperti pada tema rumah, ruangan ditata dan dibagi menjadi beberapa ruangan yang ada di dalam rumah serta dilengkapi dengan berbagai peralatan yang biasanya tersedia di ruangan tersebut. Begitu pula dengan tema pasar dan rumah sakit, kegiatan bermain peran dibantu dengan media yang berkaitan kedua tema tersebut.

Semula, pembelajaran melalui metode bermain peran dibantu oleh guru sebagai contoh. Hal ini untuk memberikan gambaran pada anak-anak yang belum tumbuh keberaniannya dalam memainkan peran. Beaty (2015:73) mengatakan, terkadang satu-satunya cara membantu anak yang enggan atau tidak mau terlibat dalam permainan adalah Anda sebagai guru atau orangtua memainkan peran itu. Oleh karena itu, guru mengawali dengan memerankan berbagai tokoh yang ada pada setiap tema, sehingga anak dapat memahami bagaimana peran dilakukan. Anak adalah komunikator pemula, orang dewasa menjadi pembantu kedua dalam komunikasi sebagai tenaga ahli yang mampu menciptakan kondisi efektif dalam percakapan (Otto, 2015: 41).

Dunia anak adalah dunia bermain. Ketika anak-anak bermain mereka akan merasakan kesenangan, kebahagian, dan rasa nyaman. Melalui metode bermain peran, selain anak terlibat langsung untuk memeragakan atau memerankan tokoh yang ada dalam cerita, sekaligus anak melakukan berbagai hal atau kegiatan yang biasa tokoh tersebut lakukan. Pada pembelajaran anak usia dini, keterlibatan anak secara langsung dalam pembelajaran sangatlah penting, Musthafa (2008: 49). Kesempatan yang luas untuk anak terlibat langsung dalam pembelajaran merupakan salah satu hal utama dalam mengembangkan kemampuan bahasa anak usia dini, salah satunya dalam hal pengembangan komunikasi.

Bermain peran pada tema rumah dapat mengasah anak untuk kembali mengingat berbagai benda dan aktivitas yang sering dilakukan orang-orang ketika berada di rumah. Ketika anak memerankan tokoh ibu, maka ia akan mengingat contohnya kegiatan memakaikan baju pada anaknya dari mulai popok, celana dalam, kaos dalam, celana panjang, kemeja, kaos kaki, sepatu, bahkan baju hangat atau jaket ketika musim dingin atau musim hujan tiba. Memerankan tokoh ayah, maka ia akan mengingat bagaimana ayah memperbaiki bagian-bagian rumah yang rusak serta menyebutkan berbagai alat yang digunakan.

Terlihat dari pembelajaran yang dilakukan pada tema rumah, pada saat prasiklus anak-anak memiliki kemampuan komunikasi yang rendah dalam menyampaikan ide, gagasan, ataupun pemikiran mereka tentang berbagai hal yang ada di rumah. Setelah diberikan tindakan melalui pembelajaran untuk mengembangkan komunikasi melalui metode bermain peran, kemampuan komunikasi anak meningkat, terutama pada poin anak mampu menyampaikan informasi pada temannya serta anak mampu memainkan peran yang dilakoninya (Brunner (1983). Bahasa paling cepat dikuasai dalam situasi bermain-main (Musthafa, 2008: $10)$.

Pada tema rumah, keberanian anak untuk mengungkapkan berbagai ide dan gagasan yang ada dalam pikirannya muncul dengan baik, karena rumah merupakan tempat yang sangat dekat dan dikenal baik oleh anak. Melalui 
metode bermain peran, anak dengan bebas dapat mengeksplorasi tokoh yang diperankannya, karena anak sadar, ini hanyalah sebuah permainan tapi sangat menyenangkan dan menjadi petualangan yang seru. Anak dapat memerankan tokoh ayah yang mereka tahu ayah adalah orang yang paling kuat di rumah. Begitu pula ketika anak memerankan tokoh ibu, terlihat mereka mendalami tokoh ibu yang memiliki sifat lemah-lembut dan penuh kasih sayang serta pintar memasak. Sedangkan anak yang memerankan tokoh anak, dia benar-benar menjadikan dirinya anak yang sebenarnya suka dengan permainan, merengek-rengek pada ibunya, dan mencium tangan kedua orangtuanya sebagai cerminan bahwa anak ini memiliki sifat yang baik.

Berikut grafik pengembangan keterampilan berkomunikasi anak usia dini melalui bermain peran pada tema rumah (gambar 2). Pada kegiatan pembelajaran pengembangan komunikasi anak usia dini melalui metode bermain peran dengan tema pasar, terlihat adanya peningkatan kemampuan komunikasi anak yang diawali dengan prasiklus hasilnya: 83 poin di mana rata-rata anak berada pada tingkat 1 , yaitu tidak pernah melakukan hal yang di minta, pada siklus kedua anak-anak rata-rata

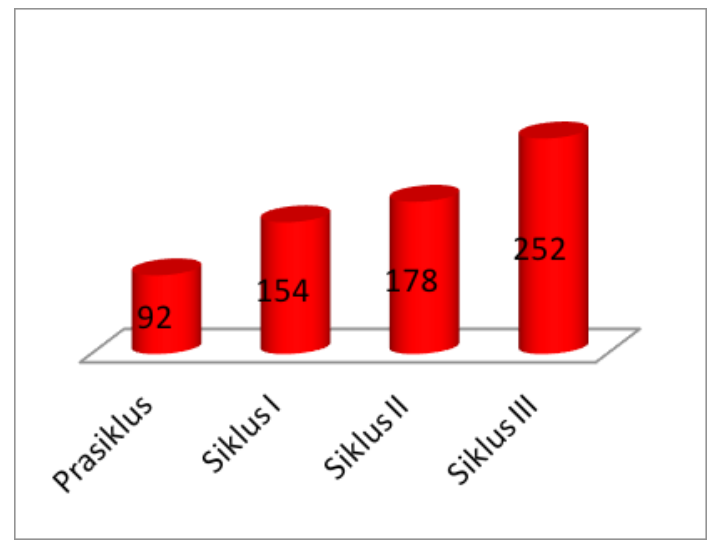

GAMBAR 2. Perkembangan Komunikasi AUD melalui Metode Bermain Peran Tema Rumah berada pada poin 1 dan 2 , di mana hal ini menggambarkan bahwa anak-anak mulai melakukan komunikasi dengan teman-temannya walaupun masih dalam taraf biasa. Pada siklus 2, angka yang diperoleh adalah 161 poin, rata-rata anak ada dalam posisi poin 2 dan 3, di mana anak-anak mulai sering melakukan komunikasi dengan teman-temannya dan mulai berani menyampaikan ide serta pemikiran dan gagasan mereka. Pada siklus 3, angka yang diperoleh adalah 244, rata-rata anak berada pada posisi 3 dan 4, hal ini menyatakan bahwa sebagian besar anak sudah mampu berkomunikasi dengan baik. Lebih jelasnya, dapat dilihat pada gambar 3 .

Tema pasar merupakan sebuah tema yang sangat dekat dengan dunia anak, dan anak-anak menyukai tempat tersebut karena di sana ia bisa membeli berbagai hal yang ia perlukan. Di pasar, anak dapat memegang berbagai barang yang ingin dia amati lebih dalam serta menanyakan berbagai harga barang yang ingin ia ketahui. Serunya suasana pasar membuat anak semakin asyik melakukan perannya, baik penjual maupun pembeli. Mereka terlihat menikmati menghitung lembaran uang yang dibuat dari kertas mainan sebagai alat untuk membeli; bahkan sebagian dari mereka terlihat

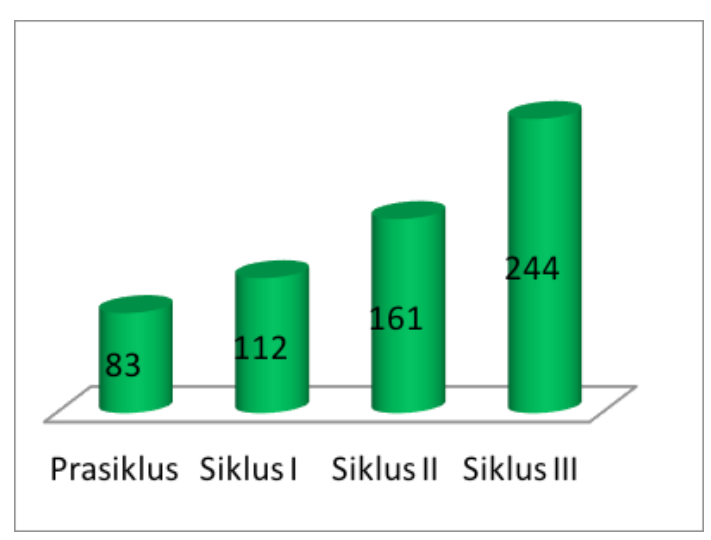

GAMBAR 3. Perkembangan Komunikasi AUD melalui Metode Bermain Peran Tema Pasar 
berpikir sejenak mengenai jumlah harga barang yang dibelinya.

Anak-anak tidak terlihat sungkan melakukan tawar-menawar harga barang dengan temannya sebagai penjual. Mereka benar-benar mengingat kegiatan tawarmenawar yang sering orangtua mereka lakukan ketika di pasar dan mereka melakukannya sekarang dalam arena bermain peran di pasar. Tampak beberapa anak beradu harga dengan penjual barang dan memilih-milih barang-barang yang bagus kualitasnya. Ada pula beberapa anak yang berkeliling dulu melihat-lihat barang dan bertanya harga-harga barang pada para penjual, kemudian mereka terlihat berpikir sambil menghitung uang di dalam dompet, baru kemudian melakukan transaksi pembelian di kios yang mereka anggap harganya murah dan barangnya bagus. Komunikasi di pasar pun berjalan lancar dan menyenangkan.

Pada pembelajaran tema yang ketiga, tema yang dipilih adalah tema rumah sakit. Tema-tema yang dipilih adalah tema-tema yang melibatkan banyak orang dan sering dikunjungi anak, sehingga anak mengetahui gambaran situasi dan bagaimana peran tokoh-tokoh yang ada dalam tema tersebut (Beaty, 2015: 433). Agar anak-anak terlibat di permainan drama mereka harus punya pengetahuan langsung tentang kegiatan yang akan dilakukan, maka tanyakanlah pada anak-anak ke mana mereka pernah pergi dan piknik. Bila anak belum pernah berkunjung dan melihat orang-orang yang akan mereka perankan, maka ajaklah anak-anak untuk berkunjung terlebih dahulu sebelum kegiatan bermain peran dilakukan.

Berdasarkan grafik pada gambar 4, prasiklus di peroleh 84 poin ratarata anak berada pada tingkat 1 , yaitu belum melakukan komunikasi dengan baik. Maka, mulailah pembelajaran menggunakan metode bermain peran. Pada siklus 1, kemampuan komunikasi

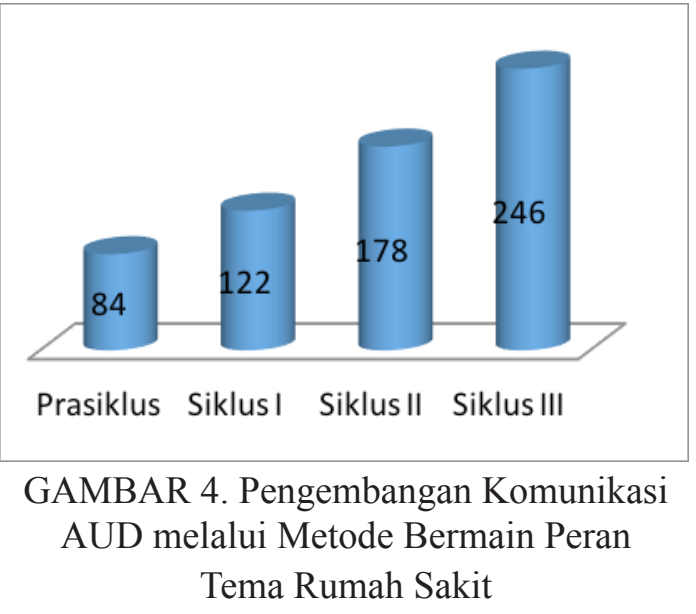

anak terlihat mulai meningkat dan mereka rata-rata berada pada poin 2, yaitu kemampuan komunikasinya mulai muncul. Pada siklus ke 2, kemampuan komunikasi anak meningkat; pada point 3 , yaitu di mana anak sudah mulai berani mengungkapkan gagasan dan ide-idenya, dan mulai dapat mendalami tokoh yang diperankannya, namun masih terlihat ucapan yang disamapikan pada temannya masih berbelit atau masih kurang dapat di mengerti dengan baik. Setelah anak-anak mendapat perlakukan selama 3 siklus, kemampuan anak dalam mengembangkan komunikasi pada tema rumah sakit sangat baik, rata-rata mereka berada pada poin 4, yang menyatakan bahwa mereka mampu melakukan komunikasi dengan teman-temannya dengan baik; bahasa yang mereka ucapkan dapat dipahami dan dapat memainkan peran yang mereka lakoni.

Rumah sakit merupakan tema ketiga dalam penelitian ini. Pada tema ini anak-anak memerankan tokoh yang sering mereka lihat di rumah sakit. Anak yang berperan sebagi dokter melakukan aktivitas layaknya seorang dokter, yaitu menanyakan pada pasien sakit: apa, sudah berapa lama sakit, sudah makan obat apa saja; memeriksa pasiennya menggunakan stetoskop, senter untuk melihat keadaan mulut dan tak lupa memegang dahi untuk mengukur tingkat 
demam pasiennya. Sang dokter pun anak berusaha untuk mengingat nama-nama obat yang sering dia dengar dari dokter ataupun orangtuanya ketika mereka membeli, ketika dia sakit kemudian purapura menuliskannya di resep yang harus dibeli oleh pasien.

Anak lain yang memerankan tokoh perawat. Dia menggunakan baju layaknya seorang perawat atau suster, yaitu berwarna putih-putih dan di kepalanya memakai topi putih kecil. Kemudian, dengan sigap mencari dan menyiapkan kartu berobat pasien, lalu menuliskan usia dan keluhan pasien pada kartu tersebut, kemudian memanggil nama pasien untuk diperiksa dokter sesuai antrean kedatangan pasien, sampai akhirnya sang perawat memberikan resep obat yang harus dibeli sang pasien. Ada pula beberapa anak yang menjadi perawat mengatakan bahwa pembayaran dilakukan di sini dan menyebutkan nominalnya, kemudian pasien pun membayar dengan nominal yang telah ditentukan.

Sedangkan anak-anak yang memerankan dirinya sebagai pasien, terlihat mereka mendalami perannya: ada yang pura-pura batuk, sakit kepala, flu, sakit perut, bahkan gatal-gatal. Dan mereka pun terlihat layaknya seperti orang sakit yang lemas, dan memerlukan bantuan untuk sekadar berdiri, bahkan berjalan pun dipapah oleh orang yang menemaninya berobat. Ada pula yang berperan sebagai ibu yang membawa berobat bayinya yang demam, anak ini terlihat menggendong boneka bayi dengan selendang dan mengayun-ayunnya agar si bayi tidak menagis. Anak-anak benarbenar peniru yang hebat. Mereka dapat mengingat hal-hal kecil yang pernah dilihat, dan terjadi pada diri dan orangorang di sekitarnya. Bahkan, mereka bisa mengingat ucapan-ucapan orang-orang yang mereka temui atau lihat, baik di rumah, pasar maupun rumah sakit.
Salah satu sarana dasar bagi berkreasi, berimajinasi, dan mengembangkan komunikasi anak usia dini, adalah melalui kegiatan bermain peran. Melalui metode bermain peran anak akan menerapkan pengalamannya secara kreatif pada kegiatan purapura (bermain peran) dan dia pun akan mengembangkan komunikasinya melalui penambahan dialog pada alur cerita yang dia perankan (Beaty, 2015: 420). Anak mengembangkan kreativitas untuk berkomunikasi sendiri saat diberi kebebasan dan waktu untuk berpartisipasi dalam permainan imajinatif (Suryadi, 2010). Gaya komunikasi anak akan terbangun dengan baik apabila anak memiliki tingkat kemampuan berpikir kreatif yang baik, dan kreativitas anak terbangun melalui kegiatan bermain peran.

Tujuan utama dari pendidikan yaitu menciptakan manusia yang bisa melakukan hal baru, tidak sekadar mengulang apa yang pernah dilakukan generasi sebelumnya (Petersen \&Wittmer, 2015: 274). Melalui bermain peran, anakanak dituntut untuk aktif berkomunikasi dengan bahasa yang mampu dipahami orang lain dan mengeksplorasi berbagai hal yang dapat memerkaya peran yang dilakoninya, sehingga dia bisa menjadi manusia yang kreatif dan inovatif.

\section{SIMPULAN}

Bermain peran merupakan metode untuk mengembangkan kemampuan imajinasi dan kreativitas anak. Pembelajaran di tingkat anak usia dini melalui metode bermain peran dapat mendorong pengembangan kemampuan sosial, bahasa, dan komunikasi anak yang lebih efektif.

Dalam metode bermain peran, tema yang diberikan adalah tema yang dekat dengan dunia anak, yaitu: rumah, pasar dan rumah sakit. Melalui tiga tema tersebut, bermain peran akan berlangsung 
lebih efektif karena anak mengetahui dan pernah melihat langsung tokoh yang akan diperankannya dan anak pernah mengunjungi tempat di mana tokoh tersebut berada. Peran media pun membantu anak dapat memerankan berbagai tokoh dengan lebih baik.

Hasil penelitian membuktikan kemampuan komunikasi anak sebelum tindakan rata-rata berada pada poin satu yaitu anak belum mampu berkomunikasi dengan baik. Namun setelah tindakan dengan mengggunakan metode bermain peran kemampuan komunikasi anak meningkat. Hal ini terlihat di siklus tiga pada masing-masing tema, di mana rata-rata kemampuan komunikasi anak berada di poin tiga, yaitu anak mampu berkomunikasi dengan baik.

Melalui metode bermain peran dengan tiga tema tersebut, menumbuhkan keberanian anak untuk mengungkapkan ide, gagasan, dan pemikirannya serta mengomunikasikan berbagai pengalaman kepada orang lain, tanpa anak merasa takut atau khawatir salah dalam pengucapannya, sehingga terbangunlah komunikasi yang baik dan efektif antara orangtua, guru atau orang dewasa lainnya dengan anak.

Inti dari komunikasi melalui metode bermain adalah menciptakan suasana yang nyaman, aman, tidak ada kesan menggurui atau menasihati. Orangtua dan orang dewasa lainnya lebih berperan sebagai teman atau partner bagi anak, sehingga komunikasi yang dibangun akan lebih bermakna bagi anak.

\section{DAFTAR PUSTAKA}

Afrilianto \& Hendriana. (2017). Penelitian

Tindakan Kelas. Bandung: Refika Aditama

Beaty. J. (2015). Observasi Perkembangan Anak Usia Dini. Jakarta: Kencana.

Dhinie, dkk. (2008). Metode Pengembangan

Bahasa. Jakarta: Universitas
Terbuka.

Doughherty.D. (2003). Bagaimana Berbicara dengan Bayi Anda. Jakarta: Anak Prestasi Pustaka

Inten. D. (2015). Mengenalkan Literasi untuk Anak Usia Dini melalui Metode Bermain Peran. Prosiding Seminar Nasional UPI, Vol. 1, Bandung.

Irawati. I. (2012). Ayo Bicara. Bekasi: Pustaka Inti.

Iriantara. Y. (2014). Komunikasi Pembelajaran. Bandung: Simbiosa.

Junita. I. (2009). Prinsip Komunikasi Efektif untuk Meningkatkan Belajar Anak. Bandung: Simbiosa.

Madyawati. L. (2016). Strategi Pengembangan Bahasa pada Anak. Jakarta: Kencana.

Morrison. G. (2012). Dasar-Dasar Pendidikan Anak Usia Dini. Jakarta: Indeks.

Musthafa. B. (2008). Dari Literasi Dini ke Literasi Teknologi. Jakarta: Yayasan CREST.

Nurani. Y. (2009). Konsep Dasar Pendidikan Anak Usia Dini. Jakarta : Indeks

Nurgiantoro. B. Sastra Anak. Yogyakarta : Gadjah Mada University Press.

Otto. B. (2015). Perkembangan Bahasa Anak Usia Dini. Jakarta: Kencana.

Petersen \& Wittmer (2015). Kurikulum Pendidikan Anak Usia Dini. Jakarta: Kencana

Pramesti.(2004).http://www.kla.or.id/ index.php?option $=$ com_cont ent\&view $=$ article $\&$ id $=129: \mathrm{k}$ ondisi-lingkungan-bermainanak\&catid $=56$ :artikel\&Itemid $=77$

Solehuddin. M. (1997). Konsep Dasar Pendidikan Prasekolah. Bandung: IKIP.

Suryadi.E.(2010). Model Komunikasi Efektif bagi Pengembangan Kemampuan Berpikir Kreatif Anak. Jurnal Ilmu Komunikasi. Vol 8, No 3.

Wiguna.(2013).http://health.kompas.com/ $\mathrm{read} / 2013 / 05 / 01 / 14171091 /$ Kenap. Balita.Tak.Boleh.Akrab.dengan. Gadget. 